HELMINTHOLOGIA, 55, 2: 127 - 133, 2018

\title{
Endoparasites of the European hare (Lepus europaeus) (Pallas, 1778) in central Italy
}

\author{
V. SERGI', G. ROMEO², M. SERAFINI ${ }^{3}$, E. TORRETTA ${ }^{3}$, F. MACCHIONI ${ }^{1 *}$
}

\begin{abstract}
'Department of Veterinary Science, University of Pisa, via Livornese lato Monte, 56122, Pisa, Italy, E-mail: *fabio.macchioni@unipi.it, sergi.valeria89@hotmail.it; 2Ufficio per le Attività Faunistico Venatorie e Ittiche dell'Amministrazione Regionale di Grosseto. Regione Toscana, Italia (Office for Hunting and Fishing Activities of Grosseto Regional Administration, Italy), E-mail: giorgina.romeo@regione. toscana.it; ${ }^{3}$ Di.S.T.A., University of Pavia, Via Ferrata 1, 27100 Pavia, Italy, E-mail: teos.teos@libero.it, torretta.elisa@gmail.com
\end{abstract}

\section{Article info}

Received September 27, 2017 Accepted February 22, 2018

\section{Summary}

Brown hare (Lepus europaeus) populations in Europe have declined through decades due to several, but not clear yet, factors. Parasite infections and diseases are some of the causes that directly affected the survival and breeding rates of animal population.

A study on the endoparasites of 70 hares ( 37 hunted free-living hares, and 33 bred on farms hares) was performed between 2015 - 2017 in the province of Grosseto (central Italy), an area where the impact of parasites in the hare population has never been investigated. During necroscopic analysis of hunted hares the following helminthes were found: Trichostrongylus retortaeformis $(87.1 \%)$, Passalurus ambiguus (12.9\%) and Andrya spp. (6.4 \%) in the intestinal tract, Protostrongylus cuniculorum (8.3 \%) in lungs and Dicrocoelium dendriticum (16.7 \%) in livers. The prevalences of the intestinal helminthes in bred hares were: $12.1 \%$ for Passalurus ambiguus and $3 \%$ for Trichostrongylus retortaeformis. The coprological analysis showed prevalences of $64.9 \%$ for coccidia in the 37 hunted hares and $45.5 \%$ in the 33 bred hares. The relationship between the intensities of parasitic infections and body weight was evaluated.

The results of the present study in the Grosseto area indicate that free-living hares have few species of parasites and that the intensities of parasitic infection did not affect their general condition and health, suggesting that endoparasites played no detectable role in the dynamics of this hare population.

Keywords: Brown hare; necroscopical analysis; coprological analysis; host-parasite

\section{Introduction}

The European hare (Lepus europaeus) is the most important game species in Europe and the most widespread hare species in Italy. Since the 1960s, there has been a general decrease in the number of hares in many European countries (Smith et al., 2005; Marboutin et al., 2003). There are several probable causes of this population decline: a reduction in the number of suitable habitats for hares due to the intensification of agriculture (Smith et al., 2005), over-hunting (Meriggi et al., 2001), the increase in the number of predators, especially the red fox (Vulpes vulpes) (Goszczynski \& Waseilewski, 1992; Knauer et al., 2010), and the spread of infectious diseases such as EBHS (European brown hare syndrome), pasteurellosis, yersiniosis and tularemia (Lamarque et al., 1996; Posauts et al., 2015). Parasite infections can also be significant negative controlling factors of hare populations in terms of being the direct cause of death and, above all, as debilitating factors (Posauts et al., 2015; Diakou et al., 2014; Kornaś et al., 2014; Chroust et al., 2012; Dubinsky et al., 2010).

The aim of the present study was to investigate the endopara-

\footnotetext{
* - corresponding author
} 
sites of both free-living and bred European hares in the province of Grosseto (Tuscany, central Italy), an area where the hare population has already been well studied (e.g. Santilli et al., 2014; Santilli \& Ferretti 2008), with the exception of the impact of parasites, which has never been investigated. In Tuscany there has been a decline of the species since the late 1960s (Santilli \& Galardi 2006). The last published data revealed a density of 9 hares $/ \mathrm{km}^{2}$ estimated in 23 protected areas in the province of Grosseto (Santilli \&Ferretti, 2008).

\section{Materials and Methods}

A total of 70 European hares were collected from 2015 to 2017 in the province of Grosseto (central Italy). 37 hares (27 females and 10 males; 7 young hares and 30 adults) were legally culled, according to Italian Law No. 157/92 and 33 hares were collected from two farms (20 females and 13 males; 7 young hares and 26 adults). All samples were taken to the Office for Hunting and Fishing in Grosseto.

The viscera were separated from the rest of the carcass by hunters or breeders, therefore in some cases not all organs of hunted hares were properly conferred. Conversely samples of all organs of bred hares were accurately collected and analysed. The samples were transferred to the Parasitology Section of the Department of Veterinary Sciences at the University of Pisa.

Individual data on the area of origin, gender, weight, and age of the hares were recorded. Hares were classified as young ( $\leq 8$ months of age) if the Stroh's tubercle was present, otherwise they were classified as adult (>8 months of age) (Stroh, 1931).

The gastro-intestinal tracts of 31 hunted hares and 33 bred hares were analysed. Intestinal mucosa was observed macroscopically, gastric contents were submitted to sedimentation and examined under a stereomicroscope. Intestines were examined with the sedimentation and counting technique (SCT) in accordance with Eckert et al. (2001).

Kidneys, urinary bladders, and spleens of 31 hunted hares and 33 bred hares were opened, washed and the sediment was examined by stereomicroscopy.

The livers of 24 hunted hares and 33 bred hares were analysed by stereomicroscopy.

The cardiorespiratory system of 24 hunted hares and 33 bred hares was examined. The trachea was examined under a stereomicroscope, pulmonary tissue smears were taken to search for eggs and larvae. Heart and lungs were cut and washed with tap water in order to collect adult parasites.

All adult parasites found were isolated, counted, separated by gender and stored in $70 \%$ alcohol and classified, according to taxonomic keys and some articles (Yamaguti 1959; Levine 1968; Soulsby 1968; Boev 1975; Durette-Desset, 1977; Audebert et al., 2000).

Rectal faecal samples (at least $3 \mathrm{~g}$ ) of all 70 hares were subjected to coprological analysis to detect parasite oocysts, eggs and lar- vae, using flotation in centrifuge with $50 \% \mathrm{ZnCl}_{2}$ (s.g. 1.300) and $\mathrm{K}_{2} \mathrm{Hgl}_{4}$ (p.s.1450) as flotation solutions, according to the procedure described by Dryden et al. (2005).

Coprocoltures of fresh faeces of bred hares were performed to obtain the coccidian oocysts sporulation in order to allow the identification of the coccidia species. Faeces with oocysts were treated with K2Cr2O7 to enable oocysts to sporulate (Eckert et al., 1995). Prevalences with $95 \%$ confidence intervals $(\mathrm{Cl})$, mean abundance, mean intensity, and range were calculated (Bush et al., 1997). Multiple parasite infections were also described. Pearson's Chi squared test and Fisher's exact test were carried out to compare parasite prevalences in hares of different age groups, genders and provenance (i.e. free-living vs. bred hares). For the most prevalent parasite, a negative binomial distribution was compared to obtained data by Pearson's Chi square test in order to investigate the stability of host-parasites relationship as an indication of overdispersion (Bliss \& Fisher, 1953). The relationship between the intensities of parasitic infections as predictor variables and body weight as a dependent variable was evaluated using Pearson correlation and the results were expressed as correlation coefficients and regression equations.

The results of the coprological tests were compared to necropsy results taken as a gold standard. The significance of the tests was confirmed for $P$ values lower than 0.05 . All the statistical analyses were carried out using Quantitative Parasitology 3.0 software (Rózsa et al., 2000) and SPSS package version 20.

\section{Ethical Approval and/or Informed Consent}

The present work did not involve the use of laboratory animals. Samples were gathered from dead free-ranging brown hares which were legally shot by hunters in accordance with Italian Law (157 of 11/02/1992). Thus, no animals were killed specifically for this study.

\section{Results}

\section{Hunted hares}

The most prevalent parasites in the intestines of hunted hares were Trichostrongylus retortaeformis (87.1\%) in the small intestine, followed by Passalurus ambiguus (12.9\%) in the large intestine, and Cestoda of the family Anoplocephalidae (9.6\%) in the small intestine. On the basis of morphologic and morphometric analyses of scolex and proglottids, the cestodes were identified as Andrya spp. (Table 1).

Of the 31 examined hares, $12.9 \%$ were negative to parasites, $67.7 \%$ were positive to one parasite species, and $19.4 \%$ presented double infections. All single infections were by T. retortaeformis, double infections were by $T$. retortaeformis and $P$. ambiguus (12.9\%), and by T. retortaeformis and Andrya spp. (6.5\%).

Comparing prevalences of intestinal parasites between genders, no significant differences were found. Between age classes, a sig- 
Table 1. Necropsy of free-living hares Lepus europaeus. Intestinal and liver helminths. NP = number of positive hares, $\mathrm{P} \%=\mathrm{Prevalence}, \mathrm{Cl} \%=95 \%$ confidence interval of prevalence, $T P=$ total number of parasites, $R=$ Range, $A=$ Abundance; $M I=$ Mean Intensity.

\begin{tabular}{|c|c|c|c|c|c|c|c|}
\hline Necropsy & NP & $\mathrm{P}(\%)$ & $\mathrm{Cl}(\%)$ & $\mathrm{R}$ & TP & A & $\mathrm{IM}$ \\
\hline \multicolumn{8}{|l|}{ Hunted hares $(n=37)$} \\
\hline \multicolumn{8}{|l|}{ Intestinal parasites ${ }^{a}$} \\
\hline Trichostrongylus retortaeformis & 27 & 87.1 & $70.1-96.3$ & $2-3650$ & 18505 & 596.9 & 685.4 \\
\hline Passalurus ambiguus & 4 & 12.9 & $3.6-29.8$ & $23-664$ & 793 & 25.6 & 198.2 \\
\hline Andrya spp. & 2 & 6.4 & $0.8-21.4$ & $1-2$ & 3 & 0.1 & 1.5 \\
\hline \multicolumn{8}{|l|}{ Liver parasites $^{b}$} \\
\hline Dicrocoelium dendriticum & 4 & 16.7 & $0.8-21.4$ & $16-610$ & 644 & 26.8 & 161.0 \\
\hline \multicolumn{8}{|l|}{ Bred hares $(n=33)$} \\
\hline \multicolumn{8}{|l|}{ Intestinal parasites } \\
\hline Trichostrongylus retortaeformis & 1 & 3.0 & - & - & 79 & 2.4 & 79 \\
\hline Passalurus ambiguus & 4 & 12.1 & $3.4-28.2$ & $1-312$ & 370 & 11.2 & 92.5 \\
\hline
\end{tabular}

The gastro-intestinal tracts of 31 hunted hares were analysed.

'The livers of 24 hunted hares were analysed.

nificant difference was observed only for $T$. retortaeformis ( $P$ value of Fisher's exact test $=0.008)$ : adult hares $(25 / 26$ hares, $96.2 \%)$ were more infected than young hares (2/5 hares, $40.0 \%$ ).

T. retortaeformis was found with a high abundance and high intensity (597 and 685 respectively), with a high total number of parasites isolated (18505), ranging from 2 to 3650 specimens.

For $T$. retortaeformis, a negative binomial distribution, with parameters $k=0.44$ and $p$ binom $=0.00074$, was found to fit the data and tested (Pearson's Chi squared $P$ value higher than 0.05 ). No correlation was found between body size and the intensity of infection of $T$. retortaeformis $(r=0.291 ; p=0.119)$.

No parasites were found in the spleen nor in the urinary system. The most prevalent parasite in the bile ducts was Dicrocoelium dendriticum found with a prevalence of $16.7 \%$. No significant differences in the prevalences between genders and age classes were observed.

In the cardiopulmonary system, no parasites were found in the hearts and tracheas of the examined hares. In the lungs of two hares, parasites of the family Protostrongylidae were found, species Protostrongylus cuniculorum. The nematodes were clustered in nodules on the lung surface. Due to the difficulty of isolating parasites from nodules, it was only possible to calculate the prevalence of the infection and not the number of parasites. In addition to adult parasites, the presence of larvae was evidenced by pulmonary smears. The prevalences were not significantly different between genders and age classes of the hosts. The species identification was established on caudal bursa according to the features proposed by Boev (1975).

Coprological analysis revealed that 30 faecal samples were positive to some parasites (Table 2).

The results of the coprological test were compared to necropsy results (considered as the gold standard) in 31 hunted hares for the most prevalent parasite Trichostrongylus retortaeformis. The sensitivity (s) of the coprological test was 0.33 and the specificity (s') was 1.00 .

A total of 24 free living hunted hares were positive to coccidia $(64.9 \%)$. There were no significant differences in the prevalences between age classes and genders. No correlation was found between body size and the intensity of infection of coccidia $(r=$ $-0.160 ; p=0.179)$.

Table 2. Coprological examination hares Lepus europaeus. NP = number of positive hares, $\mathrm{P} \%=$ prevalence, $\mathrm{Cl} \%=95 \%$ confidence interval of prevalence, $\mathrm{R}=$ Range, Mean OPG/EPG=Mean oocysts/eggs per gramme of faeces.

\begin{tabular}{cccccc}
\hline \multicolumn{1}{c}{ Coprology } & $\mathrm{NP}$ & $\mathrm{P} \%$ & $\mathrm{Cl} \%$ & $\mathrm{R}$ & Mean OPG/EPG \\
\hline Hunted hares $(\mathrm{n}=\mathbf{3 7})$ & & & & & \\
Coccidia & 24 & 64.9 & $47.5-79.8$ & $50-26600$ & 4765.2 \\
Gastro-intestinal Strongylids & 11 & 29.7 & $15.9-47.0$ & $50-200$ & 59.1 \\
$\quad$ Dicrocoelium dendriticum & 4 & 10.8 & $3.7-25.4$ & $100-600$ & 175 \\
\hline Bred hares ( $\mathrm{n}=33$ ) & & & & & \\
Coccidia & 15 & 45.4 & $28.1-63.6$ & $150-51750$ & 5037.8 \\
\hline
\end{tabular}


Table 3. Epidemiological studies on the prevalences of parasites in hares in Europe.

\begin{tabular}{lcccccccc}
\hline Country & EL $^{\mathrm{a}}$ & $\mathrm{PL}^{\mathrm{b}}$ & $\mathbf{A T}^{\mathrm{c}}$ & $\mathbf{C Z}^{\mathrm{d}}$ & $\mathbf{S K}^{\mathrm{e}}$ & $\mathbf{E S}^{\mathbf{f}}$ & Flg $^{\mathbf{g}}$ & FR $^{\mathrm{h}}$ \\
\hline $\mathrm{N}^{\circ}$ of hares & 84 & 83 & 225 & 137 & 74 & 53 & 24 & 22 \\
\hline Trichostrongylus retortaeformis & 50 & 32.5 & 82.7 & 83.2 & 6.8 & 56.6 & 54.2 & 9 \\
Passalurus ambiguus & 4.8 & 6.0 & -- & -- & 12.2 & -- & -- & 30 \\
Protostrongylus spp. & 1.2 & 4.8 & 37.3 & 18.2 & -- & -- & 33.3 & -- \\
Andrya spp. & -- & -- & 4.4 & 2.9 & -- & 34 & -- & -- \\
Dicrocoelium dendriticum & 9.5 & -- & -- & -- & -- & $11(7 / 64)$ & -- & -- \\
Coccidia & 64.3 & -- & 80.4 & 79.6 & 92 & 71.7 & 37.5 & -- \\
\hline
\end{tabular}

a Greece - Diakou et al., 2014; b Poland - Kornas et al., 2014; ' Austria - Chroustet al., 2012; d Czech Republic - Chroustet al., 2012; e Spain - Dubinsky et al.,

2010; ${ }^{f}$ Finland - Alzaga et al., 2009; ${ }^{g}$ Slovakia - Soveri \& Valtonen, 1983; ${ }^{\text {}}$ France - Bordes et al., 2007;

\section{Bred hares}

On farms, necropsy examination of the large intestine, revealed the presence of $P$. ambiguus in four hares (12\%) with relatively low abundances and T. retortaeformis in one hare (3\%). All other organs were free from parasites (Tab. 1). Coprology examination revealed that 15 hares were positive only to the coccidia genus Eimeria spp., sometimes also with cases of large infection, with the OPG ranging between 150 - 51750 (Tab. 2). Three species of coccidia were identified in the bred hares: Eimeria leporis, $E$. semisculpta, and E. europaea.

\section{Free-living vs. bred hares}

A comparison between free-living and bred hares showed significant differences in the prevalences of $T$. retortaeformis ( $P$ value of Fisher's exact test $<0.001)$, and $D$. dendriticum ( $P$ value of Fisher's exact test $=0.03$ ). For each parasite above mentioned, free-living hares $(29.7 \% ; 10.8 \%)$ were more infected than bred hares $(3 \%, 0 \%)$.

\section{Discussion}

The intestinal helminths found in hunted hares were the nematodes Trichostrongylus retortaeformis and Passalurus ambiguus, and the cestode Andrya spp.

T. retortaeformis $(87 \%, 27 / 31)$, the dominant parasite in the present study, is a commonly encountered species in the small intestine of the European hare in Italy and in other areas of Europe. With regard to previous studies in other parts of Italy, a prevalence of $72 \%$ (38/53) was found in Bologna (Stancampiano et al., 2016), where it was the only gastro-intestinal strongylid detected. In Genoa the prevalence was 65 \% (34/52) (Poglayen et al., 2002), corresponding to the lowest value in Italy. In central Italy the prevalence was 75 \% (54/72) (Poli et al., 1991). Canestri-Trotti et al. (1988) compared the prevalence of this helminth in autochthonous and imported European hares. They found a prevalence of $71.9 \%$ (59/82) in Ferrara, 90 \% (29/30) in Modena, and $100 \%$ (25/25) in hares imported from Czechoslovakia, Poland and Hungary. In the province of Pisa, a prevalence of Trichostrongylus spp. of $76.25 \%$ (22/29), accompanied by catarrhal enteritis was reported by Agrimi et al. (1981).

Considering results obtained in other European countries, we found prevalences similar to those detected in Austria and Czech Republic, while elsewhere T. retortaeformis prevalences were lower (Table 3).

We found that the distribution of $T$. retortaeformis in the host population had a negative binomial distribution, indicating a good ecological balance and equilibrium between parasites and hosts. The distribution pattern of parasites in host population has many involvements in epidemiologic studies and host-parasite dynamics (Anderson \& May, 1978; Poulin, 1993). For macro-parasites, host morbidity and mortality are strictly density-dependent and the effects will be high when parasites follow a random distribution (with a low level of variance) in host population. Consequently, an aggregate distribution (with high level of variance) positively affects the impact of parasite in host population supporting a stable interaction (Anderson \& May, 1978; May \& Anderson, 1978). The prevalence of the parasite was significantly higher in adults than in young hosts, in accordance with other studies (Stancampiano et al., 2016).

The importance of this nematode as a pathogenic agent that induces mortality or weight loss has been demonstrated by Gottschalk (1973), Haupt \& Hartung (1977) and by Boch \& Schneidawind (1988). Newly et al. (2005) reported that T. retortaeformis infection involves a strong reduction in the physical condition and fertility of females, but does not affect their survival. However, our results suggest that the intensity of parasitic infection not affect hare body size.

P. ambiguus was found in $12.9 \%$ of hares (4/31), higher than in other studies performed in Italy. In Genoa, the percentage was $3.8 \%$ (2/52) (Poglayen et al., 2002). Percentages of $7.3 \%(6 / 82)$ and $10.0 \%(3 / 30)$ were found in the provinces of Ferrara and Modena respectively, while the parasite was not found in $25 \mathrm{im}$ ported hares (Canestri-Trotti et al., 1988).

The nematode, specific to lagomorphs, lives in the cecum and anterior colon and usually does not show clinically evident signs 
(Diakou et al., 2014). It is rarely found in European hares and always with low prevalences, while it is more commonly found in wild rabbits (Oryctolagus cuniculus).

In Europe $P$. ambiguous had higher prevalences only in France (Table 3).

Andrya spp.was found in this study, with a low prevalence $6.4 \%$ (2/31). Previous studies in Italy showed the presence of the Andrya genus in Ravenna (Zanni et al.,1995). A. rhopalocephala and Cittotaenia pectinata were found in Pisa (Poli et al., 1988). A. rhopalocephala was found in $3 / 30$ hares (10\%) in Modena and in 1/25 imported hares (4\%) (Canestri-Trotti et al., 1988). Andrya cunicoli was found in 9/137 imported hares (6.5\%) in Ferrara and Modena (Canestri-Trottiet al., 1988).

In Europe Andrya spp. had higher prevalences only in Spain (Table 3).

Anoplocephalidae infestation generally does not cause any symptoms, only in case of massive infestations digestive disorders can occur (Heintzelmann-Grongroft, 1976).

In the present study $P$. cuniculorum was found in $8.3 \%(2 / 24$ hares). $P$. pulmonalis is the most common pulmonary parasite in Italy and Europe. However, in some locations in Tuscany the parasite P. cuniculorum (Joyeus \& Gaud, 1946) was found in hares with pulmonary protostrongylosis (Barbiera, 1960).

$P$. rufescens and $P$. pulmonalis were found in some repopulation and hunting areas in Pisa (Poli et al.,1988). Furthermore, Protostrongylus spp. was found in $2.7 \%(2 / 72)$ hares in the same area (Poli et al.,1991). Protostrongylus spp. was found in L. europaeus with a prevalence $14 \%$ in Ravenna (Zanni et al.,1995).

In Europe Protostrongylus spp. prevalences are very variable (Table 3).

The presence of pulmonary stronglyes often predisposes to secondary bacterial infections, leading to alterations in lung capacity and function, which considerably reduce the possibility of escape of the hare and therefore its chances of survival (Spagnesi \&Trocchi, 1992).

Dicrocoelium dendriticum was found in four livers of the 24 examined (16.6\%). Dicrocoelium spp. is mainly widespread among ruminants in pasture, but little known and often underestimated (Otranto \& Traversa, 2002). Hares may occasionally be infected in areas of ruminant grazing (Chroust et al., 2012). D. dendriticum was found for the first time in hares in Italy in one European hare, with prevalence $1.3 \%$ (1/72) (Poli et al., 1991).

It has also rarely been found in other areas of Europe (Table 3). Coccidia had similar prevalence among our samples: $64.9 \%$ $(24 / 37)$ in hunted hares and $45.4 \%(15 / 32)$ in bred hares. Genoa has the lowest prevalence (17.3\%, 9/52) (Poglayen et al., 2002). Tacconi et al., (1995) reported that in Umbria all faecal specimens of bred hares were negative for coccidia (0/867), while all free living hares in protected areas were positive $(n=1233)$. In central Italy, a prevalence $90.3 \%$ (65/72) was found (Poli et al., 1991). Coccidiosis was also found in the province of Pisa in $26.2 \%$ (8/29) of dead hares (Agrimi et al., 1981).
In Europe coccidia prevalences are generally high (Table 3).

Coccidia are among the most dangerous pathogenic parasites in hares. The combination of intestinal nematodes and coccidia are one of the major controlling factors in harbour populations (Chroust, 1984). Especially in young animals, a high level of infection can lead to severe illness and eventually to the death of the animal. However, our results suggest that the intensity of parasitic infection not affect hare body size.

By comparing the parasitic fauna of the free hares with the bred ones, the free hares were statistically more infected by parasites. These results could be expected due to the veterinary control of bred hares and the absence of intermediate hosts for the pulmonary strongyloidiasis. Furthermore, the risk of contracting bacteria and viral infections and parasites could increase based on the type of breeding farm (e.g. extensive or intensive farming) and represent an important limiting factor (Spagnesi \& Trocchi, 1992).

\section{Conclusion}

Since the 1960s, the decrease in hare populations in Europe has led to management actions aimed at halting this reduction (Marboutin et al., 2003). Fluctuations in the hare population have been attributed to many factors. However, the deterioration of animal health, strongly influenced by anthropization of the landscape, seems to be the key factor. The population density may also be influenced by various diseases, as well as by parasitic infections (Alzaga et al., 2009). The results of the present study in the Grosseto area indicate that free-living hares have few species of parasites and that the intensities of parasitic infection did not affect their general condition and health, suggesting that endoparasites played no detectable role in the dynamics of this hare population. The aggregation of the most abundance parasite found (i.e. T. retortaeformis) suggests that only a minimal part of host population would, if ever, be influenced by this infection.

The situation observed in our study area, and in particular low parasite diversity, is consistent with the low host density ( 9 hares/ $\mathrm{km} 2$ ), that probably makes parasite transmission more difficult. The critical situation of host population parallels with the low biodiversity observed in parasite community. This could eventually induce a harmful loop, since biodiversity is considered a stabilizing factor in ecological webs and the lack of specific brown hare parasites in biocoenosis may be a predisposing factor for the occurrence of exogenous and potentially dangerous parasite taxa in the hare population (Hudson et al., 2006). Parasite community has probably suffered, directly (environmental mechanisms acting on both host and parasites) or indirectly (mechanisms acting on host density and therefore on parasite transmission), the same unknown cause of brown hare decline.

Nevertheless, the good health status of the bred hares highlights a good health management of the farms. However, an in-depth analysis of the coccidia species is needed, as they had the highest prevalences in the sample studied. 


\section{Conflict of interest}

Authors state no conflict of interest

\section{Acknowledgements}

We would like to thank Dr. Maria Cristina Prati for her support with this study.

\section{References}

Agrimi, P., Mancianti, F., Polı, A. (1981): Osservazioni sulla patologia spontanea di lepri (Lepus europaeus) allo stato libero. Considerazioni sull'efficacia di misure di profilassi sanitaria e di trattamenti immunizzanti e terapeutici in gruppi colpiti da pasteurellosi e parassitosi intestinali [Observation on pathologies of free living hares (Lepus europaeus). Remarks on the efficacy of sanitary prophilaxisis and immunizing and therapeutic treatments in groups affected by Pasteurellosis and intestinal parasitosis]. Annali della Facoltà di Medicina Veteterinaria di Pisa, 34: 67 - 74 (In Italian) Alzaga, V., Tizzani, P., Acevedo, P., Ruiz-Fons, F., Vicente, J., GorTAZAR C. (2009): Deviance partitioning of host factors affecting parasitization in the European brown hare (Lepus europaeus). Naturwissenschaften, 96(10): 1157 - 1168. DOI: 10.1007/s00114009-0577-y

Anderson, R.M., May, R.M. (1978). Regulation and stability of host-parasite population interactions: I. Regulatory processes. J. Anim. Ecol., 47(1): 219 - 247. DOI: 10.2307/3933

Audebert, F., Cassone, J., Hoste, H. \& Durette-Desset, M.C. (2000): Morphogenesis and distribution of Trichostrongylus retortaeformis in the intestine of the rabbit. J. Helminthol., 74(2): 95 - 107. DOI: 10.1017/S0022149X00000135

Barbiera, A. (1960): Pulmonary strongylosis in hares, in Italy. Annali della Facoltà di Medicina Veterinaria di Pisa, 13: 19 - 25

BLISS, C.I., FISHER, R.A. (1953): Fitting the negative binomial distribution to biological data. Biometrics, 9(2): 176 - 200. DOI: $10.2307 / 3001850$

Boch, J., Schneidawind, H. (1988): Diseases of Game Animals (in German). Paul Parey, Hamburg and Berlin. 214 - 215

Boev, S.N. (1975): Protostrongylids, Fundamentals of Nematology. Helminthological Laboratory, Academy of Sciences of the USSR, Moscow. [English translation by the U.S Department of Agriculture, Washington, D.C., and Amerind Publishing Co., New Dehli, 1984,338p.]

Bordes, F., Langand, J., Feliu, C., Morand, S. (2007): Helminth communities of an introduced hare (Lepus granatensis) and a native hare (Lepus europaeus) in southern France. J. Wildl. Dis., 43(4): 747 - 751. DOI: 10.7589/0090-3558-43.4.747

Bush, A. O., Lafferty, K. D., Lotz, J. M., Shostak, A. W. (1997): Parasitology meets ecology on its own terms: Margolis et al., revisited. J. Parasitol., 83 (4): 575 - 583. DOI: 10.2307/3284227

Canestri-Trotti, G., Corradini, L., Bassi, S. (1988): Osservazioni sulle elmintiasi gastrointestinali di lepri delle province di Ferrara e Modena e lepri di importazione [Observations on gastro-intestinal helminthiasis of hares in the provinces of Ferrara and Modena and in imported hares]. Supplemento alle Ricerche di Biologia della Selvaggina, 14 (1): 317 - 321 (In Italian)

Chroust, K. (1984): Dynamics of coccidial infection of free-living and cage-reared European hares. Acta Vet. Brno, 53: 175 - 182

Chroust, K., Vodnansky, M., PIKULA, J. (2012): Parasite load of European brown hares in Austria and the Czech Republic. Vet. Med. (Praha), 57(10): $551-558$

Diakou, A., Sokos, C., Papadopoulos, E. (2014): Endoparasites found in European brown hares (Lepus europaeus) hunted in Macedonia, Greece. Helminthologia, 51 (4): 345 - 351. DOI 10.2478/ s11687-014-0251-6

Dryden, M.W., Payne, P.A., Ridley, R., Smith, V. (2005): Comparison of common fecal flotation techniques for the recovery of parasite eggs and oocysts. Vet. Ther., 6(1): $15-28$

Dubinský, P., Vasilková, Z., HuRníková, Z., Miterpáková, M., SlameČKA, J., JuRČí, R. (2010): Parasitic infections of the European brown hare (Lepus europaeus Pallas, 1778) in south-western Slovakia. Helminthologia, 47(4): 219 - 225. DOI: 10.2478/s11687-0100034-7

Durette-Desset, M.C., Chabaud, A.G. (1977): Essai de classification des Nematodes Trichostrongyloidea. Ann. Parasitol. Hum. Comp., 52: 539 - 558. DOI: 10.1051/parasite/1977525539

Eckert, J., Braun, R., Shirley, M.W., Coudert, P. (1995): Guidelines on techniques in coccidiosis research. eds. Office for Official Publications of the European Communities, Luxembourg

Eckert, J., Gemmel, M.A., Meslin, F.X., Pawlowski, Z.S. (2001): WHO/OIE Manual on Echinococcosis in Humans and Animals: a Public Health Problem of Global Concern. World Organization for Animal Health (OIE) Paris, France, pp. 265

GoszczYNSKI, J., WAselleWSKI, M. (1992): Predation of foxes on a hare population in central Poland. Acta Theriol., 37(4): 329 - 338 GotTSCHALK, C. (1973): Internal parasites of the brown hare and their role in small game hunting in eastern Thuringia (in German). Angew Parasitol., 14: $44-54$

HAUPT, W., HARTUNG, J. (1976): Endoparasitenbefall der Hasen aus der Umgebungvon Leipzig [Endoparasite infestation of hares nearby Leipzig]. Monatsh. Veterinarmed., 32: 339 - 341 (In German) HeINTZELMANN-GRÖNGRÖFT, B. (1976): Vergleichende endoparasitologische Untersuchungen bei Feldhasen (Lepus europaeus Pallas) aus verschiedenen Revieren [Comparative endoparasitological investigations in brown hares (Lepus europaeus Pallas) from different areas]. Z. Jagdwiss., 22(3): 149 - 161 (In German)

Hudson, P.J., DoBson, A.P., LAfFerTy, K.D. (2006): Is a healthy ecosystem one that is rich in parasites? Trends Ecol. Evol., 21 (7): 381 - 385. DOI: 10.1016/j.tree.2006.04.007

Joyeux, C., GAUD, J. (1946): Recherches helminthologiques marocaines. Etudes sur la pneumonie vermineuse [Moroccan helminthological research. Studies on verminous pneumonia]. Arch. de Inst. Pasteur du Maroc.,3 (6): 383 - 461 (In French) 
Knauer, F., KüChenhoff, H., PIlz, S. (2010): A statistical analysis of the relationship between red fox Vulpes vulpes and its prey species (grey partridge Perdix perdix, brown hare Lepus europaeus and rabbit Oryctolagus cuniculus) in Western Germany from 1958 to 1998. Wildlife Biol., 16 (1): 56 - 65. DOI: 10.2981/07-040

Kornaś, S., Wierzbowska, I.A., WajdziK, M., Kowal, J., Basiaga, M., NosAL, P. (2014): Endoparasites of European brown hare (Lepus europaeus) from Southern Poland based on necropsy. Ann. Anim. Sci., 14 (2): 297 - 305.DOI: 10.2478/aoas-2014-0010

Lamarque, F., Barrat, J., Moutou, F. (1996): Principal diagnoses for determining causes of mortality in the European brown hare (Lepus europaeus) found dead in France between 1986 and 1994. Gibier Faune Sauvage., 13(1): 53 - 72

LeVINE, N.D. (1968): Nematode Parasites of Domestic Animals and of Man. Urbana, USA ,Burgess Publishing Company, 600 pp.

Marboutin, E., Bray, Y., Péroux, R., Mauvy, B., Lartiges, A. (2003): Population dynamics in European hare: breeding parameters and sustainable harvest rates. J. Appl. Ecol., 40 (3): 580 - 591. DOI: 10.1046/j.1365-2664.2003.00813.x

May, R.M., Anderson, R.M. (1978): Regulation and stability of host-parasite population interactions: II. Destabilizing processes. J. Anim. Ecol., 47: 249 - 267

Meriggi, A., Ferloni, M., Geremia, R. (2001): Studio sul successo dei ripopolamenti di Lepre [An investigation of brown hare restocking success]. Bologna, Italia, Greentime, 252 pp. (In Italian)

Newey, S., Shaw, D. J., Kirby, A., Montieth, P., Hudson, P. J., THIRGOOD, S. J. (2005): Prevalence, intensity and aggregation of intestinal parasites in mountain hares and their potential impact on population dynamics. Int. J. Parasitol., 35 (4): 367 - 373. DOI: 10.1016/j.jpara.2004.12.003

Otranto, D., Traversa, D. (2002): A review of dicrocoeliosis of ruminants including recent advances in the diagnosis and treatment. Vet. Parasitol., 107 (4): 317 - 335. DOI: 10.1016/S03044017(02)00121-8

Poglayen, G., Gaglio, G., Brianti, D., Capelli, G. (2002): Monitoraggio sanitario della lepre (Lepus europaeus): la fauna parassitaria [Sanitary monitoring of hares (Lepus europeaus): parasite fauna]. In Proceedings of the LXVI Convegno nazionale SISVet, 12 - 14 Settembre, 2012, Roma, Italia, Atti SISVet, 56, pp. 100 200 (In Italian)

Poli, A., Mancianti, F., Trocchi, V., Fujone, F.E., Tenacciano, C. (1988): Influence of population density on seasonal variations of parasitic infections in European hare (Lepus europaeus, Pallas). In Proceedings of Internationalen Symposium uber die Erkrankungen der Zoo und Wildtiere, 30: pp. 313 - 319

Polı, A., Nigro, M., Gallazzı, D., Sironi, G., Lavazza, A. Gelmetti, D. (1991): Acute hepatosis in European brown hare (Lepus europaeus, Pallas). J. Wildl. Dis., 27 (4): 621 - 629. DOI: 10.7589/00903558-27.4.621

Posautz, A., Loncaric, I., Lundin, M., Hoffmann, D., Lavazza, A., Kelemen, Z., Beiglböck, C., Walzer, C., Kübber-Heiss, A. (2015): Health screening of free-ranging European brownhares (Lepus europaeus) on the German North-Sea island Pellworm. Acta Vet. Scand., 57: 43. DOI: 10.1186/s13028-015-0132-0

Poulin, R. (1993): The disparity between observed and uniform distributions: a new look at parasite aggregation. Int. J. Parasitol., 23 (7): 937 - 944. DOI: 10.1016/0020-7519(93)90060-C

Rózsa, L., Reiczigel, J., Majoros, G. (2000): Quantifying parasites in samples of hosts. J. Parasitol., 86 (2): 228 - 232. DOI: 10.1645/0022-3395(2000)086[0228:QPISOH]2.0.CO;2

SANTILLI, F., GALARDI, L. (2006): Factors affecting Brown hare (Lepus europaeus) hunting bags in Tuscany region (central Italy). Hystrix, 17(2): $143-153$

Santilli, F., Ferretti, M. (2008): Do Soils affect Brown Hare (Lepus europaeus) abundance in agricultural habitats? Hystrix, 19(1): $39-45$

SANtilli, F., PaCl, G., Bagliacca, M. (2014): Winter habitat selection by the European hare (Lepus europaeus) during feeding activity in a farmland area of southern Tuscany (Italy). Hystrix, 25(1): 51 - 53 Smith, R.K., Jennings, N.V., Harris, S. (2005): A quantitative analysis of the abundance and demography of European hares Lepus europaeus in relation to habitat type, intensity of agriculture and climate. Mammal Rev., 35(1): 1 - 24. DOI: 10.1111/j.13652907.2005.00057.x

Soulsby, E.J.L. (1968). Helminths, arthropods and Protozoa of Domesticated Animals. $7^{\text {th }}$ Edition, London, Baillière Tindall, pp. 809 Soveri, T., Valtonen, M. (1983): Endoparasites of hares (Lepus timidus and L. europaeus Pallas) in Finland. J. Wildl. Dis., 19 (41): 337 - 341. https://doi.org/10.7589/0090-3558-19.4.337

SpagnesI, M., Trocchi, V. (1992): La lepre. Biologia-Allevamento-Patologia-Gestione [The hare. Breeding Biology-Pathology-management]. Bologna, Ed. Edagricole, pp. 275 (In Italian)

Stancampiano, L., GeminianI, C., Trocchi, V. (2016): Gastro-intestinal helminth community of Lepus europaeus in Bologna province (Emilia-Romagna region): biodiversità drop in declining populations? In Proceeding of Congresso Italiano di Teriologia, 20 Aprile 2016. Acquapendente Viterbo Italia, Hystrix., 27 (Supplement), p. 22

STROH, G. (1931): Zwei sichere Altersmerkmale beim Hasen [Two safe age characteristics in rabbits]. Berl. Tierarztl Wsch., 12: 180 - 181 (In German)

Tacconi, G., Piergilı-Fioretti, D., Moretti, A., Nobilini, N., Pasquali, P. (1995): Coccidia in Hare (Lepus europaeus) Rared in Umbria, Italy: Bioepidemiological Study. J. Protozool. Res., 5 (2): 77 - 85 Yamaguti, S. (1959): Systema Helminthum. vol. II. The cestodes of vertebrates. New York. (USA), Intersciences Publisher Inc.

Zanni, M.L., Poglayen, G., Marzadori, F., Benassi, M.C., Capucci, L., Carpenè, E., Fabbi, M., Magnino, S., Tagliabue, S., Roda, R., Tasselli, A., Serra, R., Venturi, L., Bartolucci, M., Galuppi, R., Lavazza, A. (1995): Monitoraggio sanitario nella lepre (Lepus europaeus Pallas) in provincia di Ravenna [Sanitary monitoring of hares (Lepus europaeus Pallas) in the province of Ravenna]. Selezione Veterinaria, 36 (1): 1 - 25 (In Italian) 